\title{
Snakes use microhabitats created by the great capricorn beetle Cerambyx cerdo in southwest Poland
}

\author{
Iwona Gottfried ${ }^{1}$, Bartosz Borczyk ${ }^{2}$, Tomasz Gottfried ${ }^{3}$ \\ 1 Department of Behavioural Ecology, University of Wroclaw, ul. Sienkiewicza 21, 50-335 Wroctaw, Poland. \\ 2 Department of Evolutionary Biology and Conservation of Vertebrates, University of Wroclaw, ul. Sienkiewicza 21, 50-335 Wrocław, Poland. \\ 3 Polish Society of Wildlife Friends "pro Natura", ul. Podwale 75, 50-449 Wroclaw, Poland. \\ http://zoobank.org/57A6E799-D540-42FB-BD1B-B81A24A25D8B \\ Corresponding author: Iwona Gottfried (iwona.gottfried@uwr.edu.pl)
}

Academic editor: Günter Gollmann • Received 24 February 2019 • Accepted 6 April 2019 • Published 12 June 2019

\begin{abstract}
Niche engineering is considered one of the most important interspecific interactions that shape ecosystems, but this kind of interaction network has not been sufficiently studied so far. Here we present the first observation of grass snake Natrix natrix in the galleries of Cerambyx cerdo. We recorded three grass snake individuals basking and hiding inside the C. cerdo galleries. We suggest the presence of this beetle species may create new environmental niches and improve habitat quality for snakes and other vertebrates.
\end{abstract}

\section{Key Words}

ecosystem engineers, Natrix natrix, niche, saproxylic beetles

Niche engineering is among the most important interspecific interactions that shape ecosystems, and the activity of engineer species is often crucial for the existence of other species. For example, woodpeckers create tree holes used by secondary hole-nesting birds, squirrels and other animals (e.g. Lučan et al. 2009, Cockle et al. 2011, Regnery et al. 2013a). In other cases niche engineering creates conditions that are not crucial for the existence of other species, but increase their survival. However, this interaction network is still poorly understood.

One niche-engineering species is the great capricorn beetle Cerambyx cerdo (Coleoptera, Cerambycidae). It occurs in Europe, the Caucasus and the Middle East, and reaches northern Iran. The species is widespread in most parts of Europe, but has become extinct in the United Kingdom and the Swedish mainland. During the last century the species suffered a dramatic decline in central Europe (Buse et al. 2008, Zan et al. 2017). In Poland $C$. cerdo has markedly declined, and today its occurrence is limited to areas west of the Vistula River, mainly in the western and southwestern parts of the country (Kadej et al. 2017). The IUCN lists the species as vulnerable (VU; 2017.2.).

Cerambyx cerdo is one of the largest Palearctic representatives of the longhorn beetles, reaching up to $56 \mathrm{~mm}$ (length excluding the antennae). The great Capricorn beetle requires old trees (often older than 100 years) growing in sunny places (e.g. the edge of forests, meadows, dams of ponds) for reproduction (Buse et al. 2008). During development, capricorn beetle larvae create holes and cavities (galleries) that are approximately $3.5 \mathrm{~cm}$ in diameter and up to $40 \mathrm{~cm}$ in length, and have a specific microclimate (Zan et al. 2017). The corridor often ends with an approximately $10 \mathrm{~cm}$ wide oval cell. The galleries can serve as refuges for many organisms, and hence may increase the diversity and abundance of species using microhabitats created by $C$. cerdo. Previous studies have found that galleries of the great capricorn beetle were used by several other beetle species (Buse et al. 2008) and small bat species (Regnery et al. 2013b, Gottfried et al. 2019).

We describe the first record of the use of C. cerdo galleries by snakes. The observation of grass snakes $\mathrm{Na}$ - 


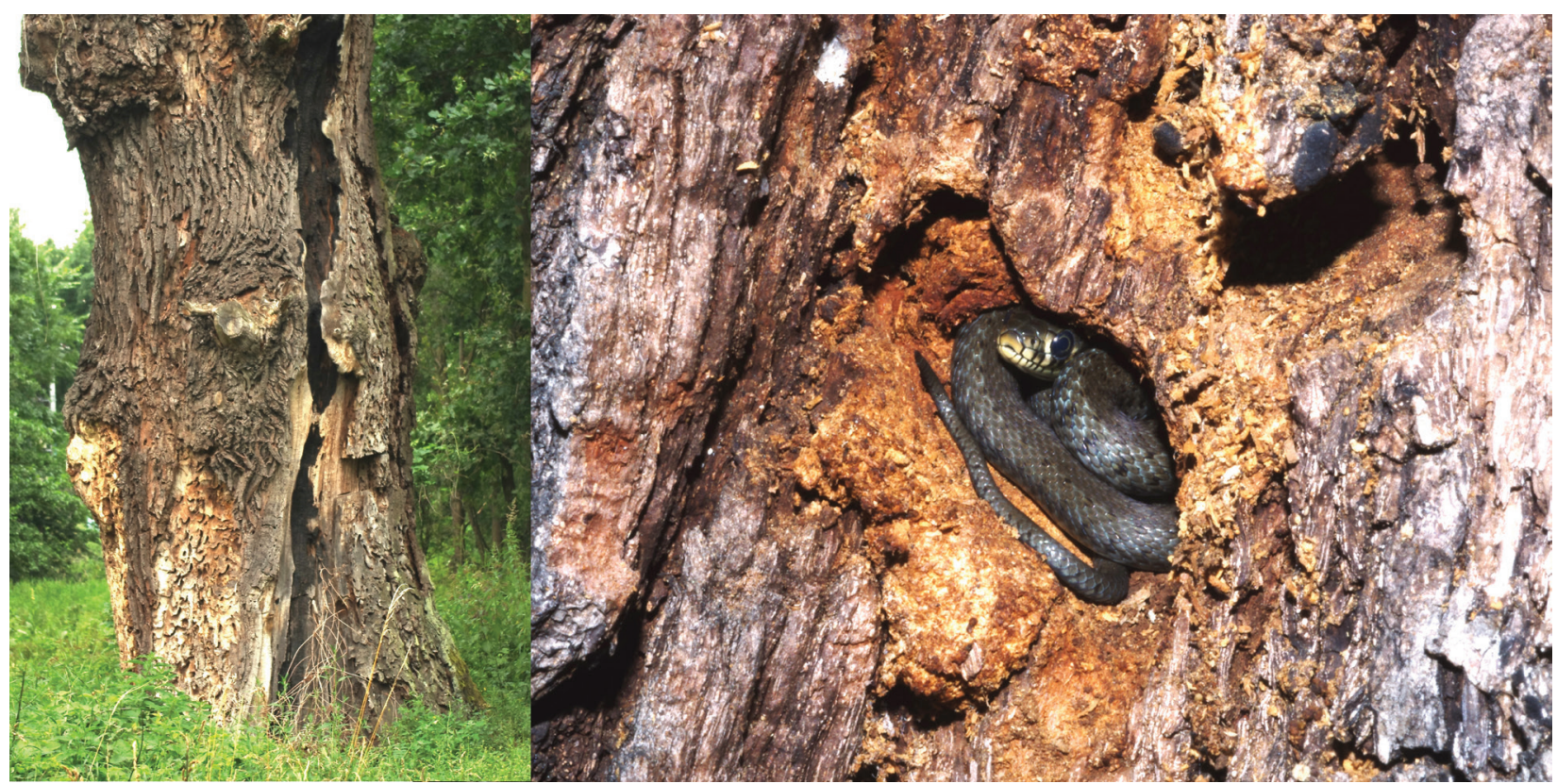

Figure 1. Grass snake Natrix natrix using larval galleries of Cerambyx cerdo.

trix natrix using galleries was conducted on 26 August 2013 on the dam of the Przelotny pond in Stawy Milickie (Milicz fish-ponds) Reserve, SW Poland. At about $16 \mathrm{~h} 00$ and $17 \mathrm{~h} 00$ we observed two snakes at a solitary, partly dead and sunlit oak (trunk circumference measured at a height of $150 \mathrm{~m}$ above ground level was $5 \mathrm{~m}$ ) for about 12 minutes from a distance of about $2 \mathrm{~m}$. During the observation, a digital camera with a telephoto $(300 \mathrm{~mm})$ lens was used. Snakes were not captured.

The first grass snake to notice was basking in the sun at the base of an old oak. After we had approached the tree, the snake crawled up the trunk and disappeared into one of the corridors at a height of approximately $1 \mathrm{~m}$ above the ground. While we were observing this snake, we noticed the second individual rolled up in another corridor at a similar height (Fig. 1). In the evening, at about 20h00, the cavities in the oak were checked again. One snake was still visible in the hole, but we noticed another small grass snake coiled in another hole, located $20 \mathrm{~cm}$ higher than two previous ones, above the line of the shadow falling on the trunk of the tree. When the sun disappeared behind the horizon and stopped shining into the hole, the snake hid inside the corridor. All individuals were observed on the western part of the trunk.

We did not catch the snakes, so we were not able to assess their size accurately, however, their length was compared to the nearby objects, which were subsequently measured. The first two individuals observed in the afternoon differed in size: the first snake had about $20 \mathrm{~cm}$, while the second one was twice as long (about $40 \mathrm{~cm}$ ). The third snake observed in the evening was about 20 cm long.

Relatively little is known about the use of tree niches by snakes. Deserted bird holes are sometimes used for egg incubation by snakes (e.g. Najbar 2004). Bryant et al.
(2011) stated that the presence of trees with holes could have an important effect for the protection of some species of arboreal snakes, such as pythons Morelia spilota, that use tree holes as resting and hiding sites. Our observation provides the first evidence for the use of the $C$. cerdo larvae corridors by grass snakes. At the same time, this is the first observation of the use of insect tree galleries by snakes.

Galleries created by $C$. cerdo larvae are extremely durable and can persist for many years, or even decades (Buse et al. 2007). Likewise, dead trees left by C. cerdo retain their ecological value as habitats for a number of organisms (Buse et al. 2008, Zan et al. 2017). Long and deep corridors of $C$. cerdo provide very stable conditions inside the gallery, offering protection from both overheating and hypothermia (O'Connell and Keppel 2016)

We suggest the use of $C$. cerdo galleries by grass snakes and other vertebrates should be studied in more detail to estimate the importance of this type of niche. However, even current preliminary observations indicate that the protection of the great capricorn beetle can be significant not only for invertebrates, but also for some small species of vertebrates, including bats (Gottfried et al. 2019) and reptiles.

\section{Acknowledgements}

We thank our department colleague Lucyna Hałupka for linguistic improvement of the text. Luca Luiselli, Günter Gollmann and an anonymous reviewer provided valuable comments on an earlier version of our paper. The study was conducted as part of the project "Bird and Bat Ecology", University of Wroclaw, under the permission number WPN.6401.164.2015. 


\section{References}

Bryant GL, Dundas SJ, Fleming PA (2011) Tree hollows are of conservation importance for a near threatened python species. Journal of Zoology (Lond.) 286: 81-92. http://doi.org/10.1111/j.14697998.2011.00852.x

Buse J, Zabransky P, Assmann T (2008) The xylobiontic beetle fauna of old oaks colonised by the endangered longhorn beetle Cerambyx cerdo Linnaeus, 1758 (Coleoptera: Cerambycidae). Mitteilungen der Deutschen Gesellschaft für allgemeine und angewandte Entomologie 16: 109-112.

Buse J, Schröder B, Assmann T (2007) Modelling habitat and spatial distribution of an endangered longhorn beetle - A case study for seproxylic insect conservation. Biological Conservation 137: 372 381. http://doi.org/10.1016/j.biocon.2007.02.025

Cockle KL, Martin K, Wesołowski T (2011) Woodpeckers, decay, and the future of cavity-nesting vertebrate communities worldwide. Frontiers in Ecology and the Environment 9: 377-382. http://doi. org/10.1890/110013

Gottfried I, Gottfried T, Zając K (2019) Bats use larval galleries of the endangered beetle Cerambyx cerdo as hibernation sites. Mammalian Biology 95: 31-34. http://doi.org/10.1016/j.mambio.2019.01.002

IUCN (2018) The IUCN Red List of Threatened Species, Version 2017.2. https://www.iucnredlist.org/species/4166/10502932 [Accessed on December 28, 2018]

Kadej M, Zając K, Smolis A, Tarnawski D, Tyszecka K, Malkiewicz A, Pietraszko M, Warchałowski M, Gil R (2017) The great capricorn beetle Cerambyx cerdo L. in south-western Poland - the current state and perspectives of conservation in one of the recent distribution centres in Central Europe. Nature Conservation 19: 111-134: http://doi.org/10.3897/natureconservation.19.11838

Lučan RK, Hanák V, Horáček I (2009) Long-term re-use of tree roosts by European forest bats. Forest Ecology and Management 258: 1301-1306. https://doi.org/10.1016/j.foreco.2009.06.032

Najbar B (2004): Wąż Eskulapa. Monografia Przyrodnicza. Nr 13. Klub Przyrodników, Świebodzin, pp. 104. [in Polish, English summary]

O’Connell C, Keppel G (2016) Deep tree hollows: important refuges from extreme temperatures. Wildlife Biology 22: 305-310. http:// doi.org/10.2981/wlb.00210

Regnery B, Paillet Y, Couvet D, Kerbiriou Ch (2013a) Which factors influence the occurrence and density of tree microhabitats in Mediterranean oak forests? Forest Ecology and Management 295: 118-125. http://doi.org/10.1016/j.foreco.2013.01.009

Regnery B, Couvet D, Kubarek L, Julien JF, Kerbiriou Ch (2013b) Tree microhabitats as indicators of bird and bats communities in Mediterranean forest. Ecological Indicators 34: 221-230. doi.org/10.1016/j. ecolind.2013.05.003

Zan LR, Bardiani M, Antonini G, Campanaro A, Chiari S, Mancini E, Maura M, Sabatelli S, Solano E, Zauli A, Peverieri GS, Roversi PF (2017) Guidelines for the monitoring of Cerambyx cerdo. The Nature Conservation 20: 129-164. http://doi.org/10.3897/natureconservation.20.12703 